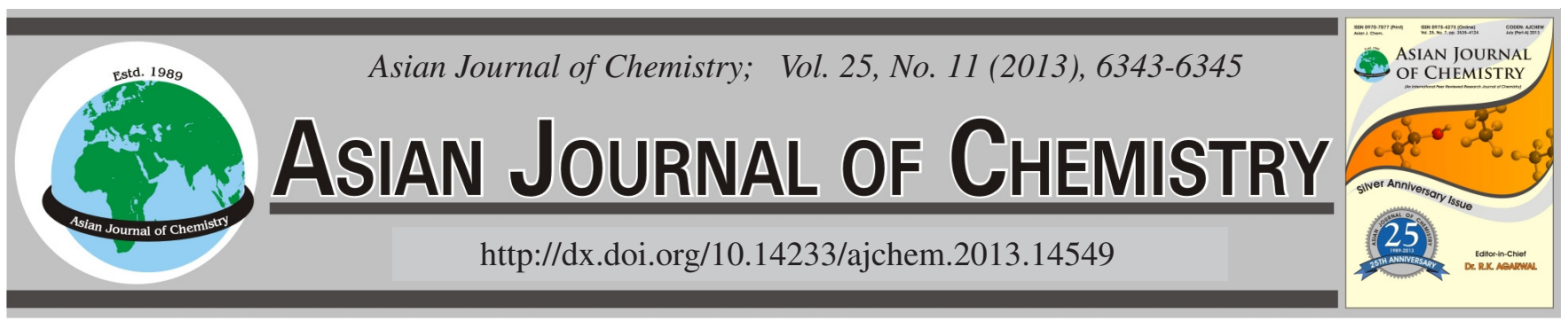

\title{
Heavy Metal Pollution Loads and Relationships of Drying Beds Sludge in Urban Wastewater Treatment Plant
}

\author{
Turgay Dere
}

Adiyaman University, Engineering Faculty, Environmental Engineering Department, Adiyaman, Turkey

Corresponding author: Email: turgaydere@gmail.com

(Received: 10 September 2012;

Accepted: 10 May 2013)

AJC-13468

\begin{abstract}
In this study, sludge samples were taken from Elazig city urban wastewater treatment plant drying beds in order to find seasonal heavy metal pollution load and to predict load variations in the samples. According to the results of the analysis, the acid extractable drying beds sludge heavy metal pollution loads were found as, respectively, iron, zinc, manganese, copper, chrome, nickel, lead, cobalt, cadmium. According to the correlation test applied to monthly pollution loads of the drying bed sludge, the highest positive correlations were observed between copper and cadmium $(p<0.01)$. After that, head sludge heavy metal pollution were found as iron-zinc, iron-nickel, iron-lead, zinc-lead, zinc-chrome, chrome-iron and nickel-zinc, respectively.
\end{abstract}

Key Words: Accumulation, Correlation test, Drying bed sludge, Heavy metal, Sewage sludge.

\section{INTRODUCTION}

The treatment sludge generated from the urban wastewater treatment plants has different heavy metals and pollution loads depending on the wastewater pollution load and treatment process. In general, treatment sludge containing heavy metals, organic pollutants, pathogenic microorganisms can cause damage to the environment during the use of various purposes ${ }^{1}$. When the treatment sludge is used as a fertilizing material, it causes soil pollution and as a result, undesired metals bioaccumulation occurs in the plants and animals in time ${ }^{2}$. Sludge's heavy metal levels are generally higher than soil, where heavy metals can be retained indefinitely in cultivated soil layers. Therefore, repeated sludge applications gradually increase the heavy metal contents of the soil. Depending on the application rate of the sludge and the concentrations of the metals and the relationships between metals, a time can be calculated. Therefore, the heavy metal concentrations in the sludge periodically must be measured and relationships between heavy metals must be investigated depending on heavy metal concentrations.

For annualy land applications, maximum heavy metal loads have to be $1500 \mathrm{mg} / \mathrm{kg}$ lead, $15 \mathrm{mg} / \mathrm{kg}$ cadmium, 1500 $\mathrm{mg} / \mathrm{kg}$ chromium, $1200 \mathrm{mg} / \mathrm{kg}$ copper, $300 \mathrm{mg} / \mathrm{kg}$ nickel and $3000 \mathrm{mg} / \mathrm{kg}$ zinc $^{3}$. Therefore $\mathrm{Pb}: \mathrm{Cd}: \mathrm{Cr}: \mathrm{Cu}: \mathrm{Ni}: \mathrm{Zn}$ rate have to be about 100:1:100:80:20:200.

Shed fertilizer Fe:Cu:Cd rate of urban sewage sludge is about 23:7:54 This rate can be available but iron requirement of land is important for land applications.
Urban wastewater sludge's $\mathrm{Zn}$ : Cd rate was found about $211: 1^{5}$. Hence this rate can be available for annually land applications.

General characteristics of sewage sludge of Bangkok were researched ${ }^{6}$. As a result, $\mathrm{Pb}: \mathrm{Cd}: \mathrm{Cr}: \mathrm{Cu}: \mathrm{Ni}: \mathrm{Zn}$ rate was about 138:1:358:4773:142:1989. So this rate isn't available for annually land applications. Because sludge heavy metal pollution loads, especially copper, zinc, nickel and chromium, are very high.

In this study, during 12 months, composite sewage sludge samples were taken from the Elazig city activated sludge treatment plant drying beds in order to investigate the heavy metal pollution loads and relationship between heavy metal pollution loads for the planned seasonal applications.

\section{EXPERIMENTAL}

Elazig city wastewater treatment plant is used for treatment both industrial and domestic wastewater. Because of that the plant's drying bed sludge's heavy metals pollution load can be variational. During 12 months, sludge samples were taken to be analyzed.

The sampling was conducted during 1 year between the dates of 15 January and 15 December. Hourly samples (for 15 day of every month) were taken from 9.30 a.m to 12.00 a.m and composite samples were prepared by mixing them. The samples were kept in the refrigerator (according to the EPA's protection appliances) prior to the analyses ${ }^{7}$. 


\begin{tabular}{|c|c|c|c|c|c|c|c|c|c|}
\hline \multicolumn{10}{|c|}{$\begin{array}{l}\text { TABLE-1 } \\
\text { MONTHLY HEAVY METAL POLLUTION LOADS IN THE DRYING BED SLUDGE OF THE ELAZIG } \\
\text { CITY URBAN WASTEWATER TREATMENT PLANT (mg/kg DRY WEIGHT) }\end{array}$} \\
\hline Months & $\mathrm{Fe}$ & $\mathrm{Zn}$ & $\mathrm{Mn}$ & $\mathrm{Cr}$ & $\mathrm{Cu}$ & $\mathrm{Ni}$ & $\mathrm{Pb}$ & $\mathrm{Co}$ & $\mathrm{Cd}$ \\
\hline January & $9,777.80$ & $1,481.90$ & 333.30 & 105.30 & 298.90 & 90.11 & 71.43 & 15.07 & 6.36 \\
\hline February & $9,444.40$ & $1,173.90$ & 333.30 & 103.50 & 265.60 & 87.50 & 66.67 & 13.09 & 6.97 \\
\hline March & $4,444.40$ & 955.60 & 182.50 & 30.80 & 118.10 & 31.10 & 31.80 & 13.33 & 1.54 \\
\hline April & $4,000.00$ & 822.20 & 157.50 & 38.50 & 107.60 & 42.22 & 34.99 & 11.11 & 1.54 \\
\hline May & $6,960.80$ & $1,013.10$ & 291.90 & 15.00 & 139.70 & 73.33 & 62.46 & 11.67 & 1.96 \\
\hline June & $5,588.20$ & 849.70 & 2.432 .00 & 15.00 & 144.20 & 44.44 & 51.75 & 10.00 & 2.48 \\
\hline July & $9,645.50$ & $1,416.70$ & 443.80 & 167.50 & 156.30 & 80.19 & 81.70 & 11.67 & 2.22 \\
\hline August & $8,299.70$ & $1,226.20$ & 656.30 & 149.00 & 156.30 & 64.95 & 68.63 & 11.11 & 2.67 \\
\hline September & $9,057.20$ & $1,387.70$ & 343.80 & 136.60 & 311.90 & 74.48 & 84.81 & 12.04 & 5.69 \\
\hline October & $7,192.90$ & $1,187.70$ & 336.30 & 73.00 & 304.00 & 45.00 & 77.43 & 8.69 & 6.12 \\
\hline November & $10,789.50$ & $1,387.70$ & 409.20 & 98.40 & 319.90 & 111.67 & 77.43 & 11.59 & 7.65 \\
\hline
\end{tabular}

The sludge samples were dried in $65^{\circ} \mathrm{C}$ for $12 \mathrm{~h}$. The dried samples were homogenized in a mortar and then sieved through $2 \mathrm{~mm}^{7}$. The sludge was processed with $5 \mathrm{~mL}$ concentrated nitric acid ${ }^{8}$ in order to measure the heavy metals concentrations. A $5 \mathrm{~mL}$ of nitric acid and $100 \mathrm{~mL}$ of distilled water was added to $3 \mathrm{~g}$ of dried sludge and the mixture is boiled until the colour becomes lighter. Then the digestate was filtered through fitler paper and the volume was completed to $100 \mathrm{~mL}$ again. The heavy metal analyses were conducted by using atomic absorbtion spectrometer ${ }^{9,7}$. Relationship between heavy metal pollution loads is correlated by SPSS-15 statistical computer program.

\section{RESULTS AND DISCUSSION}

The monthly changes of Elazig city urban wastewater treatment plant drying bed sludges's lead, cadmium, chromium, copper, nickel, zinc, iron, manganese and cobalt pollution loads and the rates among heavy metals are given in Tables 1 and 2.

\begin{tabular}{ll} 
TABLE-2 \\
& $\begin{array}{c}\text { RATES TWEEN HEAVY METAL POLLUTION } \\
\text { LOADS IN THE DRYING BED SLUDGE }\end{array}$ \\
\hline Months & $\mathrm{Pb}: \mathrm{Cd}: \mathrm{Cr}: \mathrm{Cu}: \mathrm{Ni}: \mathrm{Zn}$ \\
\hline January & $11: 1: 17: 47: 14: 233$ \\
February & $10: 1: 15: 38: 13: 168$ \\
March & $21: 1: 20: 77: 20: 621^{*}$ \\
April & $23: 1: 25: 70: 27^{*}: 534^{*}$ \\
May & $32: 1: 8: 71: 37^{*}: 517^{*}$ \\
June & $21: 1: 6: 58: 18: 343^{*}$ \\
July & $37: 1: 75: 70: 36^{*}: 638^{*}$ \\
August & $26: 1: 56: 59: 24^{*}: 459^{*}$ \\
September & $15: 1: 24: 55: 13: 244^{*}$ \\
October & $13: 1: 12: 50: 7: 194$ \\
November & $10: 1: 13: 42: 15: 181$ \\
December & $9: 1: 12: 44: 7: 175$ \\
\hline *Pb:Cd:Cr:Cu:Ni:Zn rate have to be about $100: 1: 100: 80: 20: 200$
\end{tabular}

Table-3 compares the heavy metal limit values in the sewage sludge by the European Union and the United Nations Environmental Protection Agency ${ }^{7}$.

According to metal maximum concentration limit values of the United Nations Environmental Protection Agency, $\mathrm{Pb}: \mathrm{Cd}: \mathrm{Cr}: \mathrm{Cu}: \mathrm{Ni}: \mathrm{Zn}$ rate is about 10:1:-:51:5:88. According to maximum allowable heavy metal concentrations in sewage sludge in European Union, $\mathrm{Pb}: \mathrm{Cd}: \mathrm{Cr}: \mathrm{Cu}: \mathrm{Ni}: \mathrm{Zn}$ rate is about 30:1:38:44:10:100 (Table-3).

TABLE-3

COMPARISON THE HEAVY METAL LIMIT VALUES IN THE SEWAGE SLUDGE BY THE EUROPEAN UNION AND THE UNITED NATIONS ENVIRONMENTAL PROTECTION AGENCY ${ }^{7}$

\begin{tabular}{lc|c}
\hline $\begin{array}{c}\text { Metal concentration Maximum limit } \\
\text { values of the United Nations } \\
\text { Environmental Protection Agency } \\
\text { (mg/kg dry weight) }\end{array}$ & $\begin{array}{c}\text { Maximum allowable heavy } \\
\text { metal concentrations in sewage } \\
\text { sludge in European Union } \\
\text { (mg/kg dry weight) }\end{array}$ \\
\hline Lead & 840.00 & $1,200.00$ \\
Cadmium & 85.00 & 40.00 \\
Chromium & - & $1,500.00$ \\
Copper & $4,300.00$ & $1,750.00$ \\
Nickel & 420.00 & 400.00 \\
Mercury & 57.00 & 25.00 \\
Zinc & $7,500.00$ & $4,000.00$ \\
Arsenic & 75.00 & - \\
Selenium & 100.00 & - \\
Molibden & 75.00 & - \\
Iron & - & - \\
Manganes & - & - \\
Cobalt & - & - \\
\hline
\end{tabular}

According to the results of the analysis, during 12 month, heavy metal pollution loads of the sludge in the drying beds were found to appropriate for European Union and EPA's standarts. In addition $\mathrm{Fe}, \mathrm{Mn}$ and Co concentrations in the sewage sludge were analyzed to find relationship between heavy metal pollution loads.

The correlation test was applied to January, February, March, April, May, June, July, August, September, October, November, December heavy metals pollution loads in sewage sludge. Table-4 gives the average and standard error values.

The highest positive correlation is between cadmium and copper ions. In other words when copper ions increase or decrease, cadmium ions increase or decrease. Other positive correlations are, respectively, between zinc-iron, nickel-iron, lead-iron, zinc-chromium and lead-chromium (Table-5).

\section{Conclusion}

Elazig city industrial area has about 13 different sectors. Industrial wastewaters collected urban wastewater treatment plant comprise marble industry, plastic industry, forest industry, metal products industry, electrical machinery industry, food 
TABLE-4

MEAN AND STANDARD DEVIATION VALUES FOR THE TWELVE MONTHS HEAVY METALS POLLUTION LOADS IN DRYING BED SLUDGE (mg/kg DRY WEIGHT)

\begin{tabular}{cl}
\hline Heavy Metal & From January to December \\
\hline $\mathrm{Fe}$ & $7,701.88 \pm 2,188.24$ \\
$\mathrm{Zn}$ & $1,168.18 \pm 224.31$ \\
$\mathrm{Mn}$ & $515.55 \pm 617.04$ \\
$\mathrm{Cr}$ & $84.15 \pm 51.87$ \\
$\mathrm{Cu}$ & $216.60 \pm 85.38$ \\
$\mathrm{Ni}$ & $65.90 \pm 24.41$ \\
$\mathrm{~Pb}$ & $63.85 \pm 17.24$ \\
$\mathrm{Co}$ & $10.79 \pm 3.73$ \\
$\mathrm{Cd}$ & $4.30 \pm 2.39$ \\
\hline
\end{tabular}

TABLE-5

HEAVY METALS HAVING THE HIGHEST POSITIVE CORRELATION RELATIONSHIP $(p<0.01)$

\begin{tabular}{lcccc}
\hline & $\mathrm{Zn}$ & $\mathrm{Cu}$ & $\mathrm{Ni}$ & $\mathrm{Pb}$ \\
\hline $\mathrm{Fe}$ & 0.913 & 0.755 & 0.901 & 0.874 \\
$\mathrm{Cr}$ & 0.827 & - & - & 0.728 \\
$\mathrm{Cd}$ & - & 0.965 & - & - \\
\hline
\end{tabular}

industry, textile and clothing industry, chemical industry, baked clay and cement industy, glass industry, agricultural equipment and machinery manufacturing industry, paper industry and fertilizer industry wastewaters. Depending on the industrial sectors's production potential, the heavy metal pollution loads of drying bed sludge (Plant's effluent solid waste) change.

Although the drying bed sludges's heavy metal pollution loads seem suited compared with the soil application standards, the rates tween pollution loads for continuous applications on soil may affect toxic in food cycle via the plants with long time accumulations for March, April, May, June, July, August and September sludges because of nickel and zinc. Therefore, the rates tween pollution loads should be calculated to predict toxic effect.
If drying bed sludge's copper load increase, cadmium formation of non-soluble compounds can increase in water.

If sludge's iron load increase or decrease, respectively, zinc, nickel, lead and copper loads increase or decrease. Low concentrations of zinc, copper and nickel have toxic effects in the plants. Thus these metals enter the foods and may cause negative effect the human health. When iron concentration change in sludge, zinc, nickel, lead and copper loads change. If sludge's chromium load increase or decrease, respectively, zinc and lead loads increase or decrease.

\section{REFERENCES}

1. R.P. Singh and M. Agrawal, Waste Manag., 28, 347 (2008)

2. S. Madyiwa, M. Chimbari, J. Nyamangara and C. Bangira, Phys. Chem. Earth, 27, 747 (2002).

3. D. Terz, Master Thesis, In-Year Variations in Plant Nutrients and Heavy Metal Contents of Sewage Sludges Derived from Some Wastewater Treatment Plants in Turkey, Department of Soil Science, Graduate School of Natural and Applied Sciences, Ankara University, Ankara, Turkey, pp. 4-5 (2007).

4. M.A. Bozkurt and T. Yarilga, Turk. J. Agric. Forest., 27, 285 (2003).

5. J. Ren, M.M. Cheng, R. Li, L. Liu, L.H. Wu, H.Y. Liu and Y.M. Luo, Ying Yong Sheng Tai Xue Bao, 23, 376 (2012).

6. D.D. Dacera and S. Babel, Soil Sediment Contam., 22, 457 (2013).

7. T. Dere, Eur. Researcher, 32, 1745 (2012).

8. C. Lue-Hing, D.R. Zens and R. Kuchenrither, Chemical Constituents Present Municipal Sewage Sludge and Sludge Application to Dedicated Beneficial Use Sites, Municipal Sewage Sludge Management: Processing, Utilization and Disposal, Technomic Publishing Company Inc., Lancaster, PA, Ch. 3 and 9, vol. 4 (1992).

9. N.W. Schmidtke, Sludge Generation, Handling and Disposal at Phosphorus Control Facilities in Ontario Characterization, Treatment and Use of Sewage Sludge, Proc. 2nd European Symposium, Vienna, 21-23 October 1980, pp. 190-225 (1980). 